\title{
Impact of Organizational Justice on Performance Appraisal Process and Commitment among Staff Nurses at an Oncology Hospital
}

\author{
FATMA S. ALY, M.Sc.; FATMA A. ABED, D.N.Sc. and NADIA T. MOHAMED, D.N.Sc. \\ The Department of Nursing Administration, Faculty of Nursing, Cairo University, Egypt
}

\begin{abstract}
Background: Today's organizations cannot succeed without the employees' agreement to contribute to the mission and survival of their organization. Employers and employees need to agree on their contributions. The main problem faced by any organization is how to provide an environment that facilitates the development of emotional bonds between members in order to keep talented employees in the organization.

Aim of Study: Assess the impact of organizational justice on the performance appraisal process and commitment among staff nurses at Almansura Oncology Hospital.

Material and Methods: A descriptive/correlation research design was utilized in the current study; the study was conducted at Al-Mansura Oncology Hospital.

Sample: Convenient sample of all available staff nurses who agreed to participate in the research and met the inclusion criteria was included in the study. The total number of participants was (121). Data was collected by using questionnaires to assess the impact of organizational justice on the performance appraisal process and commitment among staff nurses at Al-Mansura Oncology Hospital.
\end{abstract}

Result: The results revealed positive correlation between organizational justice and organization commitment with highly statistically significant differences.

Recommendation: The hospital should have a mechanism for explaining the effects of performance appraisal practices on the employee. Increase awareness of organizational justice and their level of organizational commitment.

Key Words: Organizational justice - Performance appraisal - Organizational commitment.

\section{Introduction}

IN the realm of organizational viewpoint and behavior, organizational justice has critical concepts

Correspondence to: Dr. Fatma S. Aly, The Department of Nursing Administration, Faculty of Nursing, Cairo University, Egypt which indeed concerning with job gratification, organizational commitment, and competent productivity. Hence, the member of staff attitudes and behaviors are affected by organizational justice. Organizational justice is essential for effective proactive management and processes by shared managers and operational executives [1].

Numerous distinct types of organizational justice contain "distributive, procedural, and interactional justice". Distributive justice is mainly concerned with the fairness of rewards. Procedural justice is improved throughout adhesiveness to "due process" standards, similar to lack of bias, truth, and consistency. Interactional justice is enhanced when personnel is treated with regard during the appraisal process. Interactional justice has been divided into "informational justice, focusing on outlet such as the adequacy of explanations, and interpersonal justice, stressing issues of politeness, and respect" [2]

Organizational justice is essential to the vital psychological contract and to a member of staff engagement and discretionary sweat. In addition, helpful in public presentation appraisal maturation. Organizational judge is concerned with the certain forms of institutional paleness in which" the welfare and burdens of an organization are allocated; the fairness of the process by which decisions are made and; the fairness of interpersonal discourse and information". Organizational justice is an intelligent tool which examines the physical process and outcomes of the performance appraisal [3].

Organizational justice approach to performance appraisal reactions is an influential approach to accepting performance appraisal reactions that indeed provided by the organizational justice perspectives. Furthermore, satisfaction with perform- 
ance appraisal system has positive appraisal results in pay rise, encouragement, training and development, awards, and incentives. Moreover, satisfaction with performance appraisal has a positive association with organizational commitment [4].

On the other side, organizational trust promotes cooperation between personnel and organizations, the organizational commitment of staffs, and the intention of the organization to retain workforces' personnel [5].

In contrast, organizational commitment of the nursing staff depends on the staff acknowledge the organizational goals, values and willingness to make efforts to improve the efficiency of the patient care in the hospital. Organizational commitment is reflected in the nursing work performance and hospital success in achieving organizational goals [6].

Organizational commitment has a positive influence on staff's behavior and desired outcomes. Commitment denotes to the binding forces that push an individual to a particular course of action with the purpose of achieving a certain goal [7] Organizational commitment can be measured within three major components; (normative, affective and continuance). Essentially, those three components of organizational commitment outlook for a psychological state of mind that suggests that self remains with an organization or not. Therefore, Organizational Commitment is influenced by Organizational Justice (OJ). Moreover, vast numbers of researches emphasis on the relationship between, organizational justice, organizational commitment, and performance appraisal [8] .

\section{Subjects and Methods}

A descriptive correlation research design was utilized. A sample of convenience of 121 nurses (pilot sample included) who agreed to participate in the research and met the inclusion criteria will be included in the study nurses who are providing direct care and have more than three years of experience in the current setting. Total capacity (17) bed emergency room and (50) bed for ICU.

The current study was conducted at Mansoura Oncology Hospital. The departments that were selected from the hospital was Intensive Care Unit and Emergency Department, from Sept. 2017 March 2018.

Data was collected by using questionnaire in an Arabic language:

1- Performance appraisal tool was developed by [9].
2- Organizational commitment tool was developed by $[10]$.

3- OrganizationalJustice questionnaire sheet. This tool was developed by [11] and was modified by the researcher to be applicable for measuring healthcare workers organization justice from his/her perspectives.

After reviewing related literatures and content validated by supervisors the questionnaire was divided into:

- Section A: Was used to gather data related to job title, education, experience, certifications, sex, age, training courses, and marital status.

- Section B: Contains questions that used to measured organizational justice as perceived by staff nurses. It was including (24) items to identify nursing staff perception toward the organizational justice in the selected hospitals.

- Section C: Contains items that used to performance appraisal process as perceived by staff nurses. It was including (72) items to identify nursing staff perception toward the performance appraisal process in the selected hospitals.

- Section D: Contains items that used to measure the organizational commitment as perceived by staff nurses. It was including (24) items to identify nursing staff perception toward the organizational commitment in the selected hospitals.

\section{Results}

A sample of convenience of 121 nurses (pilot sample included) who agreed to participate in the research and met the inclusion criteria will be included in the study nurses who are providing direct care and have more than three years ofexperience in the current setting. Total capacity (17) bed emergency room and (50) bed for ICU.

Table (1) shows that, the majority of nurses $(71.9 \%)$ were female, $(67.0 \%)$ were married, $(46.3 \%)$ of them had bachelor's degree. While, more than half of nurses $(53.7 \%)$ had experience more than 10 years, $(52.9 \%)$ had worked as a staff nurse, $(95.0 \%)$ of them were proud of nursing profession and $67.0 \%$ of them attended training course.

Table (2) shows that $(64.5 \%, 67.8 \% \& 70.3 \%)$ of the study subjects had low agreement regarding to distributive justice, procedural fairness \& fair dealings. In relation to total organizational justice, 
two-thirds of the study subjects $(66.9 \%)$ had low agreement regarding total organizational justice.

Table (1): Percentage distribution of demographic characteristics of nurses $(n=121)$.

\begin{tabular}{|c|c|c|}
\hline Items & No & $\%$ \\
\hline \multicolumn{3}{|l|}{ Age in year: } \\
\hline $20-25$ & 15 & 12.4 \\
\hline $25-30$ & 43 & 35.5 \\
\hline $30-35$ & 38 & 31.4 \\
\hline$\geq 35$ & 25 & 20.7 \\
\hline Mean \pm SD & \multicolumn{2}{|c|}{$28.6 \pm 2.4$} \\
\hline \multicolumn{3}{|l|}{ Gender: } \\
\hline Female & 87 & 71.9 \\
\hline Male & 34 & 28.1 \\
\hline \multicolumn{3}{|l|}{ Marital status: } \\
\hline Single & 30 & 24.8 \\
\hline Married & 81 & 67.0 \\
\hline Widow & 5 & 4.1 \\
\hline Divorced & 5 & 4.1 \\
\hline \multicolumn{3}{|l|}{ Qualification: } \\
\hline Bachelor & 56 & 46.3 \\
\hline Technical associate diploma & 40 & 33.1 \\
\hline Tech. Diploma nurse & 25 & 20.6 \\
\hline \multicolumn{3}{|l|}{ Experience years: } \\
\hline$<5$ years & 30 & 24.8 \\
\hline $5<10$ years & 26 & 21.5 \\
\hline$\geq 10$ years & 65 & 53.7 \\
\hline \multicolumn{3}{|l|}{ Occupation: } \\
\hline Director of nursing & 22 & 18.2 \\
\hline Nursing supervisor & 35 & 28.9 \\
\hline Staff nurse & 64 & 52.9 \\
\hline \multicolumn{3}{|l|}{ Proud of nursing profession: } \\
\hline Yes & 115 & 95.0 \\
\hline No & 6 & 5.0 \\
\hline \multicolumn{3}{|l|}{ Attend training courses: } \\
\hline Yes & 81 & 67.0 \\
\hline No & 40 & 33.0 \\
\hline
\end{tabular}

Table (2): Percentage distribution of the study nurses' perception level of organizational Justice regards total organizational justice $(n=121)$.

\begin{tabular}{lccccccc}
\hline \multirow{2}{*}{ Items } & \multicolumn{2}{c}{ Low } & \multicolumn{3}{c}{ Moderate } & \multicolumn{2}{c}{ High } \\
\cline { 2 - 7 } & No & $\%$ & No & $\%$ & No & $\%$ \\
\hline Distributive justice & 78 & 64.5 & 17 & 14.0 & 26 & 21.5 \\
Procedural fairness & 82 & 67.8 & 24 & 19.8 & 15 & 12.4 \\
Fair dealings & 85 & 70.3 & 23 & 19.0 & 13 & 10.7 \\
\hline Total organizational justice & 81 & 66.9 & 21 & 17.4 & 19 & 15.7 \\
\hline
\end{tabular}

Table (3) shows that $66.1 \%, 71.9 \%$ \& $74.4 \%$ of the study subjects had low agreement regarding to reaction toward last performance appraisal, reaction toward supervisor \& reaction toward performance appraisal. In relation to total satisfaction, less to three-quarters of the study subjects $(71.1 \%)$ had low agreement regarding total satisfaction.

Table (3): Percentage distribution of the study nurses' satisfaction regards performance appraisal system $(\mathrm{n}=121)$.

\begin{tabular}{|c|c|c|c|c|c|c|}
\hline \multirow{2}{*}{ Items } & \multicolumn{2}{|c|}{ Low } & \multicolumn{2}{|c|}{ Moderate } & \multicolumn{2}{|c|}{ High } \\
\hline & No & $\%$ & No & $\%$ & No & $\%$ \\
\hline $\begin{array}{l}\text { - Reaction toward last } \\
\text { performance appraisal }\end{array}$ & 80 & 66.1 & 21 & 17.4 & 20 & 16.5 \\
\hline $\begin{array}{l}\text { - Reaction toward } \\
\text { supervisor }\end{array}$ & 87 & 71.9 & 18 & 14.9 & 16 & 18.2 \\
\hline $\begin{array}{l}\text { - Reaction toward } \\
\text { performance appraisal }\end{array}$ & 90 & 74.4 & 16 & 18.2 & 15 & 12.4 \\
\hline Total satisfaction & 86 & 71.1 & 18 & 14.9 & 17 & 14.0 \\
\hline
\end{tabular}

Table (4) shows that $71.9 \%, 67.7 \% \& 73.5 \%$ of the study subjects had low agreement regarding emotional commitment continue commitment \& normative commitment respectively. In relation to total satisfaction toward performance appraisal, the above table illustrates that $71.1 \%$ had low agreement regarding total organization commitment.

Table (4): Percentage distribution of the study nurses' perception of organizational commitment regards total organization commitment $(\mathrm{n}=121)$.

\begin{tabular}{lcccccc}
\hline \multirow{2}{*}{ Items } & \multicolumn{2}{c}{ Low } & \multicolumn{2}{c}{ Moderate } & \multicolumn{2}{c}{ High } \\
\cline { 2 - 7 } & No & $\%$ & No & $\%$ & No & $\%$ \\
\hline Emotional commitment & 87 & 71.9 & 18 & 14.9 & 16 & 18.2 \\
Continue commitment & 82 & 67.7 & 22 & 18.2 & 17 & 14.0 \\
Normative commitment & 89 & 73.5 & 18 & 14.9 & 14 & 11.6 \\
\hline $\begin{array}{l}\text { Total organization } \\
\text { commitment }\end{array}$ & 86 & 71.1 & 19 & 15.7 & 16 & 18.2 \\
\hline
\end{tabular}

Table (5) clarified positive correlation between organizational justice and satisfaction with performance appraisal with statistically significant differences at $p<0.05$.

Table (6) clarified positive correlation between organizational justice and organization commitment with highly statistically significant differences at $p<0.01$. 
Table (5): Correlations between Organizational Justice and satisfaction with performance appraisal.

\begin{tabular}{lcccc}
\hline \multirow{2}{*}{ Satisfaction } & \multicolumn{4}{c}{ Organizational Justice } \\
\cline { 2 - 5 } & $\begin{array}{c}\text { Distributive } \\
\text { Justice }\end{array}$ & $\begin{array}{c}\text { Procedural } \\
\text { fairness }\end{array}$ & $\begin{array}{c}\text { Fair } \\
\text { dealings }\end{array}$ & $\begin{array}{c}\text { Total } \\
\text { Organizational Justice }\end{array}$ \\
\hline Reaction toward last performance appraisal & $0.73^{*}$ & $0.76^{*}$ & $0.74^{*}$ & $0.75^{*}$ \\
Reaction toward supervisor & $0.71 *$ & $0.73^{*}$ & $0.79^{*}$ & $0.76^{*}$ \\
Reaction toward performance appraisal & $0.63 *$ & $0.65^{*}$ & $0.63 *$ & $0.66^{*}$ \\
\hline Total satisfaction & $0.63^{*}$ & $0.70^{*}$ & $0.76^{*}$ & $0.72^{*}$ \\
\hline
\end{tabular}

Table (6): Correlations between Organizational Justice and Organization Commitment.

\begin{tabular}{lcccc}
\hline \multirow{2}{*}{ Organization commitment } & \multicolumn{3}{c}{ Organizational Justice } \\
\cline { 2 - 5 } & $\begin{array}{c}\text { Distributive } \\
\text { Justice }\end{array}$ & $\begin{array}{c}\text { Procedural } \\
\text { fairness }\end{array}$ & $\begin{array}{c}\text { Fair } \\
\text { dealings }\end{array}$ & $\begin{array}{c}\text { Total } \\
\text { Organizational Justice }\end{array}$ \\
\hline Emotional commitment & $0.86^{* *}$ & $0.84^{* *}$ & $0.82^{*}$ & $0.86^{* *}$ \\
Continue commitment & $0.83^{* *}$ & $0.87^{* *}$ & $0.86^{* *}$ & $0.85^{* *}$ \\
Normative commitment & $0.81^{*}$ & $0.86^{* *}$ & $0.84^{* *}$ & $0.86^{* *}$ \\
\hline Total Organization Commitment & $0.84^{* *}$ & $0.85^{* *}$ & $0.84^{* *}$ & $0.85^{* *}$ \\
\hline
\end{tabular}

\section{Discussion}

The present study aimed to assess the impact of organizational justice on performance appraisal process and commitment among staff nurses. The findings of this study answer the following research question, what is the impact of organizational justice on performance appraisal process and commitment among staff nurses.

The finding of the current study regarding to personal characteristic data revealed that the majority of the nurses more than three quarters were female, more than two-thirds were married, less than half of them had bachelor's degree. Meanwhile, more than half of the study nurses had experience more than 10 years, more than half of them had worked as staff nurse, most of them near to hundred percent of them were proud of nursing profession and more than two third of them had attended training course.

The current study revealed that near to threequarters of the study subjects had low agreement regarding to distributive justice, procedural fairness $\&$ fair dealings. In relation to total organizational justice and two-thirds of the study, subjects had low agreement regarding total organizational justice. However, the lowest percentage was for distributive justice. From point view of investigator, this result could be due to staff nurses not receiving the debated superiors about their practical decisions in the enterprise, staff nurses not receiving attention to their views from supervisors before decision equality, staff nurses not receiving the decisions regarding their work take after sufficient information and that they're not perceiving match abilities and practical tasks with performance, also not perceiving the bonus of extra effort from their superiors that do at work.

The results of the current study were consistent with [12]. This study showed that overall nurses' perceptions of organizational justice and workplace deviance are lower than the average. Also, [13] explained that, the perceived organizational justice was identified average approximately. On the other hand, the present study was inconsistent with [14] Showed that, perceived organizational justice which was believed to be higher than average which is congruent with the present results.

The present study revealed that near to threequarters of the studied sample had low satisfaction regarding performance appraisal system reaction toward last performance appraisal, reaction toward supervisor, reaction toward performance appraisal. This finding could be because that the staff nurses might think the performance process was subjective and not on significant criteria.

This result is congruent with the study of [15] which found that the nurses in study units were hardly satisfied with the performance appraisal process. On the other hand, the current study was inconsistent with the study of [16] who observed that increases in perceptions of positive treatment resulted in an increased likelihood of tenants viewing the process as fair, the outcome as fair. 
The present study showed that near to threequarters of the nurses perceived, had low agreement regarding emotional commitment, continue commitment \& normative commitment respectively. In relation to total satisfaction toward performance appraisal moreover, the present study illustrates that near to three quarters had low agreement regarding total organization commitment. From the viewpoint of the investigator, this may be because of not receiving their rewarding thanks to the organization in building their career. Also, receiving that the organization isn't the place prefers to work at.

The current study results are consistent with the study of [17] and the study of [18] their results reveal moderate level of organizational commitment perception from the staff. Also, the study of [19] have weak predictor towards the organizational commitment this result is incongruent with the study of [20] which revealed that staff commitment to their agencies and its predictors is positive and statistically significant. Also, the studyof [21] which revealed that, nurses had high levels of organizational commitment also, supported by the study of [22] which mentioned that, their employees have high commitment level however stress.

The current study shows clear positive correlation between organizational justice and satisfaction with performance appraisal with statistically significant differences at $p<0.05$. The study of [19] is consistent with the current study. Their results show that there is a relationship between distributive justice of performance appraisal and organizational commitment. The final stage of the evaluation process will be the resource allocation in which those who excellently performed will be rewarded with promotion, compensation and etc. Thus, if the distribution of resource is fairly conducted, the employees will be more committed towards the organization.

There is a relationship between interactional justice of performance appraisal and organizational commitment. The study of [23] was consistent with our study. Their results show that there is a relationship between distributive justice of performance appraisal and organizational commitment. Also, the study of [24] supported the results of the current study that there was a clear positive correlation between organizational justice and organizational commitment.

\section{Conclusion:}

There was a statistically significance positive correlation between nurse's perception of organi- zational justice and performance appraisal fairness, also their was positive correlation between nurses perception of organizational justice and satisfaction with performance appraisal with statistically significant, and their was positive correlation between nurses perception of organizational justice and organization commitment with high statistically significant.

\section{References}

1- DINC, M SAIT, KUZEY, CEMIL, and STETA, NEJRA: Nurses' job satisfaction as a mediator of the relationship between organizational commitment components, 2018.

2- CHEN, SU-YUEH, WU, WEN-CHUAN, CHANG, CHING-SHENG, LIN, CHIA-TZU, KUNG, JUNGYUAN, WENG, HUI-CHING, et al.: Organizational justice, trust, and identification and theireffects on organizational commitment in hospital nursing staff. BMC health services research, 15 (1): 363, 2015.

3- AJALA E.M.: Perceived correlation between organisational justice and employees' organisational citizenship behaviours in the civil service of Ondo and Oyo State, 2016.

4- FEELEY, MALCOLM M.: Two models of the criminal justice system: An organizational perspective Crime, Law and Society (pp. 119-137): Routledge, 2017.

5- COLQUITT, JASON A., and RODELL, JESSICA B.: Measuring justice and fairness. Oxford handbook of justice in the workplace, 187, 202, 2015.

6- SHARMA, JYOTI, and DHAR, RAJIB LOCHAN: Factors influencing job performance of nursing staff: Mediating role of affective commitment. Personnel Review, 45 (1): 161-82, 2016

7- IFTIKHAR, UMER: The Dynamics of Organizational Justice: Analyzing the Role of Trust and Job Embeddedness in Augmenting Organizational Effectiveness. National Defence University (NDU) Islamabad, 2016.

8- RAHMAN, ASIM, SHAHZAD, NAVEED, MUSTAFA, KIRAN, KHAN, MUHAMMAD FAYAZ and QURASHI, FAIZAN: Effects of organizational justice on organizational commitment, 2016.

9- MOHRMAN Jr., ALLAN M., RESNICK-WEST, SUSAN M., LAWLER III, EDWARD E., DRIVER, MICHAEL J., VON GLINOW, MARY ANN and PRINCE, J. BRUCE: Designing performance appraisal systems: Aligning appraisals and organizational realities: Jossey-Bass, 1989.

10- MEYER, JOHN P., ALLEN, NATALIE J. and SMITH, CATHERINE A.: Commitment to organizations and occupations: Extension and test of a three-component conceptualization. Journal, 1993.

11- COLQUITT, JASON A., CONLON, DONALD E., WESSON, MICHAEL J., PORTER, CHRISTOPHER O.L.H. and NG, K. YEE: Justice at the millennium: A meta-analytic review of 25 years oforganizational justice research. Journal of applied psychology, 86 (3): 425, 2001.

12- HASHISH E.A.A.: Nurses' perception of organizational justice and its relationship to their workplace deviance. Nursing Ethics, 27 (1): 273-88, 2020. 
13- HATAM N., FARDID M., and KAVOSI Z.: Perceptions of organizational justice among nurses working in university hospitals of shiraz: A comparison between general and specialty settings. Nursing and midwifery studies, 2 (4): 77, 2013.

14-HAGHIGHINEZHAD G., ATASHZADEH-SHOORIDEH F., ASHKTORAB T., MOHTASHAMI J. and BARKHORDARI-SHARIFABAD M.: Relationship between perceived organizational justice and moral distress in intensive care unit nurses. Nursing ethics, 26 (2): 46070, 2019.

15- ALY N.A.E.F.M., GHANEM M., and EL-SHANAWANY S.: Organizational Cynicism and its Consequences on Nurses and Quality of Care in Critical Care and Toxicology Units. Journal of Education and Practice, 7 (8): 85-96, 2016.

16- HOQUE K., WASS V., BACON N., and JONES M.: Are high-performance work practices (HPWPs) enabling or disabling? Exploring the relationship between selected HPWPs and work-related disability disadvantage. Human Resource Management, 57 (2): 499-513, 2018.

17- TOP M., AKDERE M. and TARCAN M.: Examining transformational leadership, job satisfaction, organizational commitment and organizational trust in Turkish hospitals: Public servants versus private sector employees. The International Journal of Human Resource Management, 26 (9): 1259-82, 2015.

18- TSAI Y.: Learning organizations, internal marketing, and organizational commitment in hospitals. BMC health services research, 14 (1): 152, 2014.
19-KRISHNAN, RAMESH, BINTI AHMAD, NUR AZREEN FARIHAH, and HARON, HAZLIZA: The Effect of Employees' Perceived Fairness of Performance Appraisal Systems on Employees' Organizational Commitment. International Journal of Academic Research in Business and Social Sciences, 8 (3): 448-65, 2018.

20- JIANG, SHANHE, LAMBERT, ERIC G., JIN, XIAOHONG, XIANG, DEPING, SHI, MENGFEI, and ZHANG, DAWEI: Correlates of organizational commitment among community correctional officers in China. The Prison Journal, 98 (1): 60-82, 2018.

21- CHEGINI Z., JANATI A., ASGHARI-JAFARABADI M. and KHOSRAVIZADEH O.: Organizational commitment, job satisfaction, organizational justice and self-efficacy among nurses. Nurs. Pract. Today, 6 (2): 83-90, 2019.

22- BHATTI M.H., BHATTI M.H., AKRAM M.U., HASHIM M., and AKRAM Z.: Relationship between job stress and organizational commitment: An empirical study of banking sector. E3 Journal oF Bussiness Management and Economics, 7 (1): 029-037, 2016.

23- KRISHNAN, RAMESH, BINTI AHMAD, NUR AZREEN FARIHAH, and HARON, HAZLIZA: The Effect of Employees' Perceived Fairness of Performance Appraisal Systems on Employees' Organizational Commitment. International Journal of Academic Research in Business and Social Sciences, 8 (3): 448-65, 2018.

24- KAUL S., and SINGH A.: Organizational justice as an enhancer of organizational commitment. The International Journal of Indian Psychology, 4 (2/89): 52-70, 2017. 


\section{آثر العدالة التنظيمية على عملية تقيييم الآداء والإلتزام

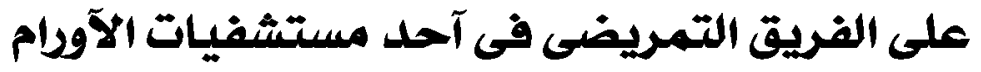

تسهم العدالة التنظيمية فى تهدئة سلوك الموظفين وموافقتهم التى تتعلق بالعدالة فى مكان العمل وتركز على زيادة إدراك العدالة العالت التنظيمية

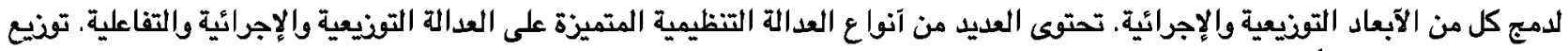

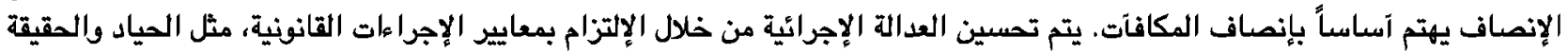

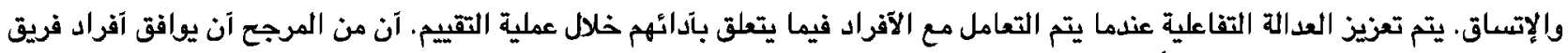

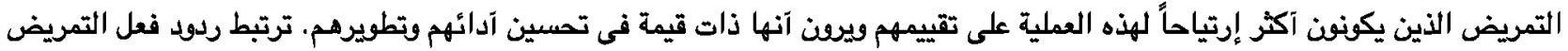

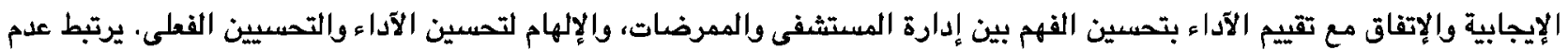

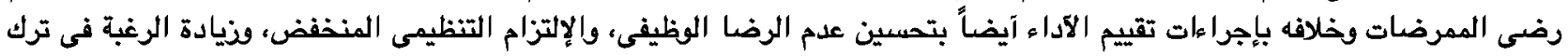

كان الهدف من البحث هو تقييم تآثير العدالة التنظيمية على عملية تقييم الآداء والإلتزام بين الممرضات فى إحدى مستشفيات الآودام.

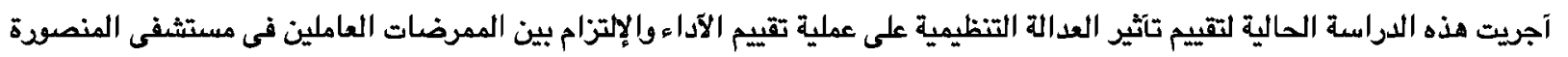

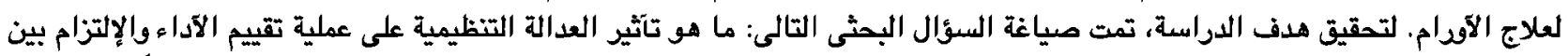

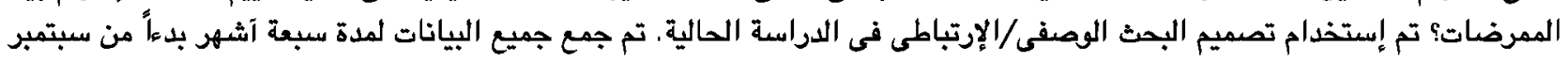

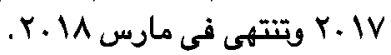

مكان البحث: تم تطبيق الدراسة فى مستشفى الآودام الجامعى بالمنصورة شاملة آقسام العناية المركزة.

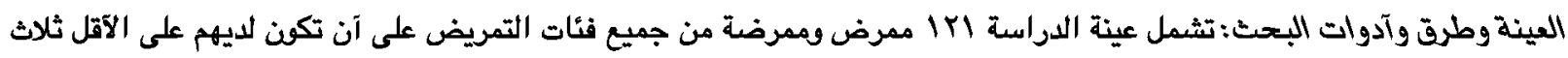

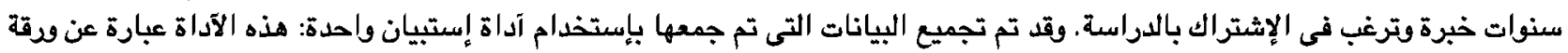
إستبيان باللغة العربية.

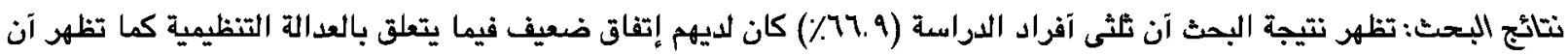

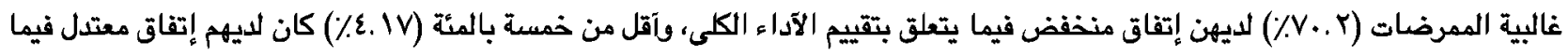

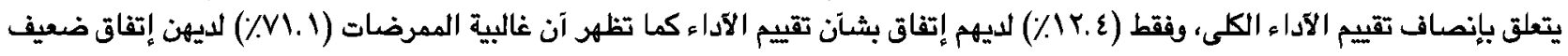

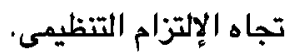

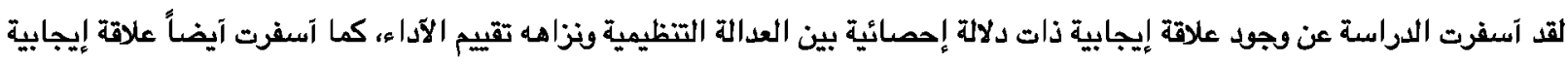

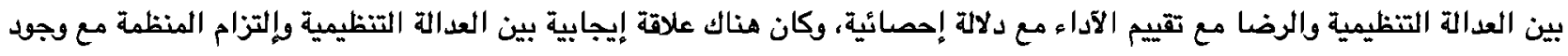

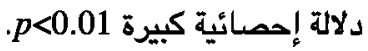

